\title{
Foot-and-mouth Disease: Global Status and Future Road Map for Control and Prevention in India
}

\author{
Bramhadev Pattnaik · Saravanan Subramaniam • Aniket Sanyal • \\ Jajati K. Mohapatra $\cdot$ Bana B. Dash $\cdot$ Rajeev Ranjan $\cdot$ Manoranjan Rout
}

Received: 3 October 2011/Accepted: 5 January 2012/Published online: 18 April 2012

(C) NAAS (National Academy of Agricultural Sciences) 2012

\begin{abstract}
Foot-and-mouth disease (FMD) is a transboundary, economically devastating and highly contagious viral disease of livestock, most importantly cattle, buffalo and pig. The disease also affects goats, sheep, wild ruminant species and elephants. The causative FMD virus is antigenically diverse having seven distinct serotypes and many variants within them. Being a single stranded RNA virus, it confirms the quasispecies nature with emergences and reemergences of different genetic lineages with altered antigenicity within the serotypes, making vaccination based control programme a high cost effective, time consuming and difficult to achieve. As per the OIE and FAO, the disease is a major threat to food security of the world, and particularly the countries having the disease are more prone to food insecurity. Further, FMD free status is an indicator of development, and all developed countries are free from it. The disease is endemic in India and three serotypes of the virus viz; $\mathrm{O}, \mathrm{A}$ and Asia1 are circulating. Annual direct loss due to FMD in India has been estimated at Rs. 20,000 crores. Many countries in the world are now free from FMD with or without vaccination and presence of the disease in other neighboring countries is a major threat to them. Countries having FMD face trade barrier posed by FMD free countries, causing heavy economic loss to the livestock industry. Progressive control pathway has been developed by FAO for global eradication of FMD. Vaccination based FMD control programme is in operation in India which involves biannual vaccinations of all cattle and buffaloes in selected areas, regular active surveillance and antibody monitoring in vaccinated population with the objective of creating FMD free zones. At present, the disease occurrence, severity of the clinical disease and number of outbreaks have progressively and substantially declined in the control zones as a result of last 10 rounds of vaccination with an oil adjuvanted trivalent inactivated vaccine. In this review, FMD scenario in India and in the world is briefed. Besides, the measures taken for the control and eradication of this devastating disease is presented. Besides, the initial success achieved through the FMD control programme in India, a road map for the control and eradication of FMD at national level is discussed.
\end{abstract}

Keywords Foot-and-mouth disease $\cdot$ FMD virus $\cdot$ Molecular epidemiology $\cdot$ FMD control programme

\section{Introduction}

Foot-and-mouth disease (FMD) is a highly infectious and contagious disease of domestic and wild ruminants and pigs. The disease also affects deer, camels, llamas, alpacas, and Asian and African elephants. Though rarely fatal in

B. Pattnaik $(\bowtie) \cdot$ S. Subramaniam $\cdot$ A. Sanyal ·

J. K. Mohapatra · B. B. Dash · R. Ranjan · M. Rout

Project Directorate on Foot-and-mouth disease, Mukteswar-

Kumaon, Nainital 263138, Uttarakhand, India

e-mail: pattnaikb@gmail.com adult animals, FMD is the most feared infectious animal disease owing to nearly $100 \%$ morbidity, rapid spread, severe decrease in livestock production, and mortality in young animals. The causative agent, FMD virus (FMDV) belongs to genus Aphthovirus in the family Picornaviridae. The virus exists as seven distinct serotypes $(\mathrm{O}, \mathrm{A}, \mathrm{C}$, Asia1 and Southern African Territories (SAT) 1-3 and multiple subtypes in each serotype [26]. Vaccination or recovery from infection, with one serotype does not protect against infection from other serotypes and sometimes against another subtype within the same serotype. Wide host range, ability of the virus to infect animals with a small dose, 
rapid rate of virus replication, high level of viral excretion and multiple modes of transmission aggravate the FMD outbreak scenario. Regular vaccination and restriction of animal movement are the major mode of disease control. Stamping out and strict zoo sanitary measures have also been adopted in America [64] and some other countries to eradicate the disease.

\section{History of FMD}

The first written description of FMD probably occurred in 1514, when Hieronymus Fracastorius described a similar disease of cattle in Italy. In Germany, existence of FMD was first reported in 1754, while in Great Britain it was first recorded in August 1839, in United States of America in 1870 and, a year later in South America [51]. Australia has been free of FMD since 1872 and it never occurred in New Zealand [5]. Early history of FMD in Africa and Asia is not known except for South Africa where the disease was first officially recorded in 1892 [68]. In India, the earliest record of FMD dates back to 1864 when it occurred in many parts of the country.

In 1898, Loeffler and Frosch discovered that the causative agent of FMD was filterable and in 1922, Vallée and Carré first showed the existence of two immunological serotypes of FMDV by cross-immunity tests in cattle. They were designated by their areas of origin, $\mathrm{O}$ (Oise, France) and A (Allemagne, Germany). Soon after, Waldmann and Trautwein in 1926 reported the existence of three immunologically distinct serotypes, A, B and C. Comparison of these virus types revealed that types A and B were the same as Vallée and Carré's types $\mathrm{O}$ and A, respectively, but type C was distinct [15]. Later in 1940s three distinct serotypes, designated as SAT-1, 2 and 3 were identified in Africa [14]. The seventh serotype, designated as Asia 1, was first recognized in the early 1950s amongst the viruses isolated from India in 1951 and 1952 [23].

\section{FMDV Genome}

FMDV has a single stranded, positive sense RNA genome, approximately about 8,500 nucleotides in length, and enclosed within icosahedral protein capsid made up of sixty copies of each structural proteins (VP1-VP4). The genome has a single open reading frame (ORF), flanked by two untranslated regions (UTRs). A small viral protein, VPg, is covalently linked to the $5^{\prime}$ end of viral RNA [58]. The $5^{\prime}$ UTR is over 1,300 bases in length and contains short fragment (SFUTR) followed by ploy $\mathrm{C}$ tract and long fragment (LFUTR). SFUTR is about 360 bases in length, and capable of folding into a long stem loop [44] which is speculated to protect FMDV genome from exonuclease activity in infected cells. Poly $\mathrm{C}$ tract is believed to play a role in virus replication and its length varies from 100 to 400 bases. LFUTR, which is over 700 bases in length, forms a number of highly conserved secondary structures that include pseudo knots (PKs), a cis-acting replication element (cre), and internal ribosome entry site (IRES). FMDV IRES is responsible for cap independent translation and is about 450 bases in length. FMDV ORF encodes single polyprotein and is divided into $\mathrm{L}, \mathrm{P} 1, \mathrm{P} 2$ and $\mathrm{P} 3$ regions. Leader proteinase $\left(\mathrm{L}^{\mathrm{pro}}\right)$ coding region located at $5^{\prime}$ end of $\mathrm{ORF}$, codes for $\mathrm{L}^{\text {pro }}$ which cleaves host cell translation factor eIF4G resulting in shut-off of host cap dependent mRNA translation [22].

$\mathrm{P} 1$ region of the genome encodes four viral structural proteins (SP) viz; VP4, VP2, VP3, and VP1 $\left(5^{\prime}-3^{\prime}\right)$. Three dimensional arrangements of structural proteins provide antigenic sites that elicit response to vaccination or infection. In addition, these structures mediate binding to cell receptors and entry of the virus into host cells. P2 region of the poly protein is processed into three mature polypeptides, 2A, 2B, and 2C [53]. 2A peptide remains associated with the P1 structural protein precursor following primary cleavage and appears to be an auto proteinase [57]. The picornaviral $2 \mathrm{~B}$ and $2 \mathrm{C}$ proteins have been implicated in virus-induced cytopathic effects. $\mathrm{P} 3$ region of poly protein is processed into four mature polypeptides; $3 \mathrm{~A}, 3 \mathrm{~B}, 3 \mathrm{C}$ and 3D. FMDV can be differentiated from other picornaviruses by a longer $3 \mathrm{~A}$ protein and three copies of $3 \mathrm{~B}$. $3 \mathrm{~A}$ protein has been implicated in adaptability of the virus in guinea pig and chicken embryo [45]. Besides, porcinophilic property of Taiwan serotype $\mathrm{O}$ isolate was attributed to a large deletion in 3A region [9]. The 3C protein of FMDV is a proteinase responsible for most cleavages in viral poly protein [70], while 3D protein is a viral-encoded RNA polymerase. $3^{\prime}$ UTR which is about $90-100$ base long, follows the stop codon and presumed to harbor some cisacting sequences required for initiation of replication.

In all FMD viruses the C-terminus and GH loop of VP1 are highly exposed regions on the capsid and are central to both antigenicity and receptor binding [33]. Several overlapping B-cell epitopes present in the GH loop, are able to induce both neutralizing and non-neutralizing antibody responses [46]. High sequence variability found in this region accounts for the low cross reactivity observed among different serotypes. Highly conserved arginineglycine-aspartic acid (RGD) motif in the variable GH loop involved in recognition of integrins receptors [33], plays an important role in viral entry into the cell and pathogenesis.

Five neutralizing antigenic sites have been reported for serotype $O[20,35,74]$. Three of these sites viz; 1,3 and 5 are found in VP1. Antigenic site 1 is formed by the $\beta \mathrm{G}-\beta \mathrm{H}$ loop and carboxy terminus of VP1 with critical residues at position 144, 148, 154 and 208. Residues 43 and 44 of the 
$\beta \mathrm{B}-\beta \mathrm{C}$ loop of VP1 contributes to site 3 whereas site 5 , characterised by an amino acid at position 149 of VP1, is probably formed by interaction of the VP1 G-H loop region with other amino acids of the capsid. Antigenic site 2 is found in VP2 with key residues at position 70-73, 75, 77 and 131. Aminoacid residues at position 58 and 60 of VP3 have been reported to be critical for antigenic site 4 . In case of serotype A, four antigenic sites in VP1, VP2 and VP3 [8, $12,37,66]$; which were analogous to sites $1,2,4$ and 5 of serotype $\mathrm{O}$ have been described. Four independent antigenic sites (I, II, IV in VP1, VP2, and VP3, respectively and site V located at C-terminus of VP3) have been mapped [32] in FMDV serotype Asia1. In type $C$, site $A$ is located in VP1 with critical residue at site 146. Site C (about 15 residues) is located in the carboxy terminal of VP1. The third site, Site D, which is the major antigenic site of type C [38], includes the B-C loop of VP2 (residues 70-80) and the B-B knob of VP3 (residues 56-61) and part of carboxy-terminal (residue 193) of VP1.

\section{Evolution of FMDV}

FMDV genomes are believed to have evolved primarily through genetic drift driven by error-prone replication of RNA genome, recombination, large population sizes, and high number of replication cycles per unit time [26]. High mutation rates during replication allow FMD viruses to evolve continuously and adapt to new environments. This extreme variability of FMDV led to the agreement that natural populations of FMDV exist as related but non-identical mutant population termed as 'quasispecies' [27]. Despite high heterogeneity of FMDV populations, there is a potential for long-term conservation of sequences due to continuous selection of a same consensus sequence in a situation of equilibrium [50]. Whenever this equilibrium is ruptured, rapid evolution and selection of new master sequences take place. One of the most troubling consequences of genetic variability is antigenic diversity. Antigenic variants have been isolated under variable conditions, such as in partially immune animals, persistently infected cattle [30] and in cell culture [24] both in presence or absence of immune pressure. Therefore, antigenic variants result from the high mutation rates during RNA replication and from the negative selection of most of the mutant phenotypes. This antigenic diversity has serious implications in vaccine design.

\section{Diagnosis of FMD}

Complement fixation test (CFT) has been used extensively for distinguishing different serotypes of FMD virus [13]. The test initially carried out in glass tubes was later modified as micro-CFT conducted in 96 well microtiter plates [21]. This test was criticized largely for its lack of sensitivity and specificity. Later, with the advent of cell culture techniques, neutralization test in microtitre plates using two fixed doses of virus and two-fold dilutions of sera was employed and found to provide a satisfactory means of differentiation between strains [54]. Subsequently, serum neutralization test was recommended as the in vitro test for assessment of antigenic variation in field strains, as it correlated well with cattle protection test [56]. Abu Elzein and Crowther [1] introduced the technique of enzyme-linked immunosorbent assay (ELISA) for FMDV diagnosis. Indirect sandwich ELISA was found to be more sensitive than CFT, and ELISA results were much more reproducible. Sandwich ELISA using FMDV anti-146S rabbit immunoglobulin as capture antibody and anti-146S guinea pig sera as tracing antibody was successfully applied in FMD diagnosis [11, 46]. This ELISA was used for characterization of Indian isolates of type $O$ [48] and Asia 1 [41] FMD virus. Liquid phase blocking ELISA using FMDV specific sera for characterization of field isolates was used and results were well correlated with conventional virus neutralization test [40]. Nucleic acid based diagnostic methods like PCR, multiplex PCR and real time PCR have been used for FMDV serotyping with improved sensitivity and specificity [65, 72]. Differentiation of FMDV-infected from vaccinated animals (DIVA) based on the detection of antibodies to nonstructural protein (NSP) 3ABC, 3AB, 3A, or 3B by ELISA is currently practiced [63]. As on today, the tests used for FMD diagnosis are either ELISA based or genome based depending on the application. However, serum/virus neutralization assays in suitable cell culture system are still preferred in vaccine matching studies.

\section{Vaccine Development}

The first experimental vaccine for FMD was prepared in 1926 using formaldehyde inactivated vesicular fluid from infected calves by Vallée, Carré and Rinjard [36]. However, the first inactivated adjuvanted vaccine for use in field was developed using formaldehyde for virus inactivation and aluminium hydroxide gel as adjuvant by Waldmann in 1937 [36]. Later, large-scale production of the virus was obtained by using surviving tongue epithelium from cattle by Frankel in 1947 [25]. Industrial production of inactivated vaccines was started by replacing tongue epithelium culture with pig kidney or baby hamster kidney (BHK) cells for virus cultivation for vaccine production. Further advancements in inactivated FMD virus production included the growth of FMDV in BHK cell suspension cultures in the 1960s [17], the introduction of ethyleneimines for 
FMDV inactivation [16], and the use of oil-adjuvant in the 1970s. Currently, a trivalent binary ethyleneimine (BEI) inactivated oil adjuvanted vaccine containing serotypes $\mathrm{O}$, $A$ and Asial is being produced and used in India. The payload of each antigen (serotype) in this polyvalent vaccine generally varies from 1 to $10 \mu \mathrm{g}$, depending on the antigenicity of the strain, Serotypes $O$ and SAT 2 vaccines require more antigen payload compared with serotypes $\mathrm{A}$ and Asia1 [25, 47].

Vaccination has been proven to be an efficient method of FMD control. Although current FMD vaccines can protect animals from clinical infection, there remains the possibility of virus replication in the oro-pharynx of sub clinically infected animals, leading to carrier status in ruminants [47]. FMD vaccines also work as marker vaccines when they are free from non-structural proteins (NSPs). Though the current vaccine provides protection against clinical disease, it still does not provide sterile immunity. Therefore, there is a need to develop an alternate vaccine with novel Toll-like receptors (TLR) adjuvants that could stimulate balanced Th1 and Th2 responses, thereby making the vaccine more efficacious [47]. As antigenic diversity is a major concern for FMD control, vaccine matching and selection are important exercises that need to be concurrent with the vaccination based control programme. Finally, to build up and maintain herd immunity at or greater than $90 \%$, it is required that all animals are vaccinated regularly at 6 months intervals.

\section{Economic Loss Due to FMD Outbreaks}

FMD infection in the livestock causes significant drop in milk yield (minimum 25\%), reduction in meat and wool production, crippled agricultural draught power, and abortion in pregnant animals, poor semen quality in bulls, and increased mortality in calves. Trade barrier for export of FMD infected livestock and their products and massive expenditure spent by Government(s) on FMD control and treatment of ailing animals also cause a great economic loss to the countries endemic to FMD. Furthermore, prolonged convalescence, short term immunity with no interserotype cross protection, and establishment of carrier status complicates the control and eradication of this devastating disease.

\section{Economic Loss in FMD Free Countries}

FMD threatens food security of the world. Besides, FMD virus is a potent agent for bio-terrorism. There are two recent examples of magnitude of loss due to occurrence of FMD. The United Kingdom experienced a severe FMD outbreak in 2001 which started in February. By September
30, 2001 when the outbreak was effectively controlled, 2026 cases of FMD were confirmed, over 6 million animals were destroyed, and the disease spread to Ireland, France and the Netherlands. The losses to agriculture and the food chain amounted to about $£ 3.1$ billion. Agricultural producers suffered losses, estimated at $£ 355$ million, which represents about $20 \%$ of the estimated total income from farming in 2001 [67].

Republic of Korea has been experiencing an ongoing outbreak in cattle and swine since 29 November 2010. As of 15 February 2011, 147 outbreaks in six provinces and four major cities have been reported. About 3.37 million pigs, cows, goats and deer were culled and buried at a cost of almost 2 billion USD in direct expenses and compensation to the farmers. Indirectly, it caused loss of market for associated supplies to the cattle and swine industries like feed, bedding and transportation etc. [28].

\section{Economic Loss in Endemic Country (India)}

Livestock is an important agriculture sector and plays a vital role in the economy of the country. India has FMD susceptible livestock population of 528 million (Department of Animal Husbandry, Dairying \& Fisheries (DAHD\&F), Government Of India, 2007). The overall contribution of livestock sector to the agricultural gross domestic product (GDP) increased from 14 to $25 \%$ over the last two decades and has consistently accounted for over $4 \%$ of the country's GDP. Milk is the largest contributor to the Indian National GDP among agricultural commodities and contributes to about $70 \%$ of total livestock sector output in India. As per estimate in a study [61, 62], loss in milk production due to FMD was 3,508 million $\mathrm{kg}$ (Rs. 12,520 million in terms of foreign exchange and Rs. 16,500-18,370 million in terms of loss of domestic surplus), and losses due to loss of draught power, animal deaths and cost of treatment were to the tune of Rs. 18,130 million/year. Direct loss amounting to Rs. 20,000 crore/ annum has been recently reported [73]. Eighty percent of the total direct loss caused by FMD is due to drop in milk production [39].

\section{Management of FMD Epidemics}

Without Vaccination

FMD eradication was possible in US, UK, Canada, Japan, Mexico, Brazil and several other countries by regular coordinated mass vaccination, control of animal movements, quarantine practices and strict zoo-sanitary measures. In UK, the 2001 FMD epidemic was controlled by culling animals in infectious premises and pre-emptive 
culling intended to limit the spread of disease [29]. The policy for control evolved over the course of the epidemic, involved animal movement restrictions and restriction of public access to affected areas. This was coupled with slaughter of animals on infected premises (IPs) and on farms identified as having had dangerous contacts (DCs) with an IP, together with the introduction of biosecurity measures such as, the use of disinfectant on clothing, boots and farm vehicles. These measures slowed spread but were insufficient to reverse it, largely owing to long delays between the report of possible FMD outbreaks and confirmation of infection, and culling of animals on the affected farm [29]. With assistance from the army in the logistics of culling large numbers of animals, in late March 2001, the operation was strengthened to cull animals on IPs and contiguous premises (CPs) within 24 and $48 \mathrm{~h}$, respectively, without waiting for laboratory confirmation of infection. Additional culling of sheep on farms within $3 \mathrm{~km}$ of an IP was also made in heavily affected areas, together with significant voluntary slaughter of sheep in the same regions from farms outside $3 \mathrm{~km}$ [29]. The disease was eradicated in October 2001.

\section{With Vaccination}

A major epidemic of FMD was seen in Argentina from July 2000 through January 2002. A combination of vaccination and restriction of livestock movement was used to control the epidemic. From the beginning of the epidemic, livestock movements were restricted throughout Argentina and herds in contact with outbreak herds were vaccinated twice ( $\sim 21$ days apart). Although in-contact herds continued to be vaccinated between September 2000 and March 2001, movement restrictions were imposed on outbreak affected as well as in contact herds. These restrictions lasted at least $\sim 30$ days after detection of the last clinical case of FMD within each herd. In early 2001, a new FMD virus variant within serotype A emerged and the number of outbreaks in Argentina increased again. As a consequence, the FMD epidemic was reported to the Office International des Epizooties (OIE) and the diseasecontrol strategy was redesigned. Between 13th March and 3rd April 2001, a complete restriction on livestock movements was re-imposed nationwide. A new vaccine containing four strains of FMD virus (O1 Campos, A24 Cruzeiro, A Argentina/2000, A Argentina/2001) was formulated. An initial round of mass-vaccination was conducted in the affected region of Argentina between April and July 2001. The epidemic could not be controlled until $\sim 6$ months after the end of the first round of mass-vaccination. Subsequent rounds of vaccination were conducted in 2002. It suggests that although this strategy can be useful in controlling large epidemics, the time required until control is achieved can be very long in large FMD epidemics [49].

\section{Global Status of FMD and Control Measures/Strategies}

Epidemiological studies of FMD across the globe have shown differential distribution of FMDV serotypes in the regions of the world. The cumulative incidence of FMDV serotypes show that six of the seven serotypes $(\mathrm{O}, \mathrm{A}, \mathrm{C}$, SAT-1, SAT-2, SAT-3) have occurred in Africa, while four $(\mathrm{O}, \mathrm{A}, \mathrm{C}, \mathrm{Asia}) \mathrm{i})$ in Asia and Europe [71], and three $(\mathrm{O}, \mathrm{A}$, C) in South America. FMD virus serotypes $\mathrm{O}$ and $\mathrm{A}$ are circulating in the Middle East, regarded as the region in the world most heavily affected by FMD. The situation in the Middle East and North Africa constitutes a threat to other regions of the world, especially Europe [2]. The conjectured status of FMD showing approximate distribution of regional virus pools is given in Fig. 1 .

Currently, FMDV serotype $\mathrm{C}$ appears to have vanished from the globe. The last type $\mathrm{C}$ outbreak was in East Africa and Asia in 1996. Though the reason for disappearance of serotype $\mathrm{C}$ from many parts of the world is unknown [34], it is widely considered to be the first candidate for global eradication. Serotypes $O$ is the most widely prevalent serotype in the world, including India and is the major serotype causing recent outbreaks in many disease free countries. Serotype A possesses greater geographical spread than any of the other serotypes. It is also the most antigenically diverse Eurasian serotype with large number of variants in Asia, Africa and South America [4, 69]. Recently, global diversity of FMDV serotype A has been elucidated $[42,43]$. The serotype Asial virus was never found outside of Asia except for a brief occurrence in Greece in 2000 [34]. It is considered to be genetically the least diverse among all serotypes [3,71]. The serotypes SAT 1-3 have a natural reservoir in the African buffalo [18] and are characterized by their large degree of antigenic diversity $[6,7]$. These three SAT serotypes are limited to Africa. However, some incidences were encountered in the Middle East involving SAT1 and 2 serotypes but these could not establish there [2]. There are many enigmas in the behavior of different serotypes of FMD virus, most of which cannot be explained [34].

\section{Control Measures}

Immunological diversity in prevalent serotypes and topotypes, in addition to uncontrolled animal movement and presence of reservoir host has made it difficult to control FMD in Asia and Africa. Historically, FMD control and eradication was achieved in Europe and North America primarily through vaccination, movement restriction and stamping out of infected and in-contact animals. The United States of America eradicated FMD in 1929 [52]. FMD was eradicated from Mexico in 1947, again in 1954 


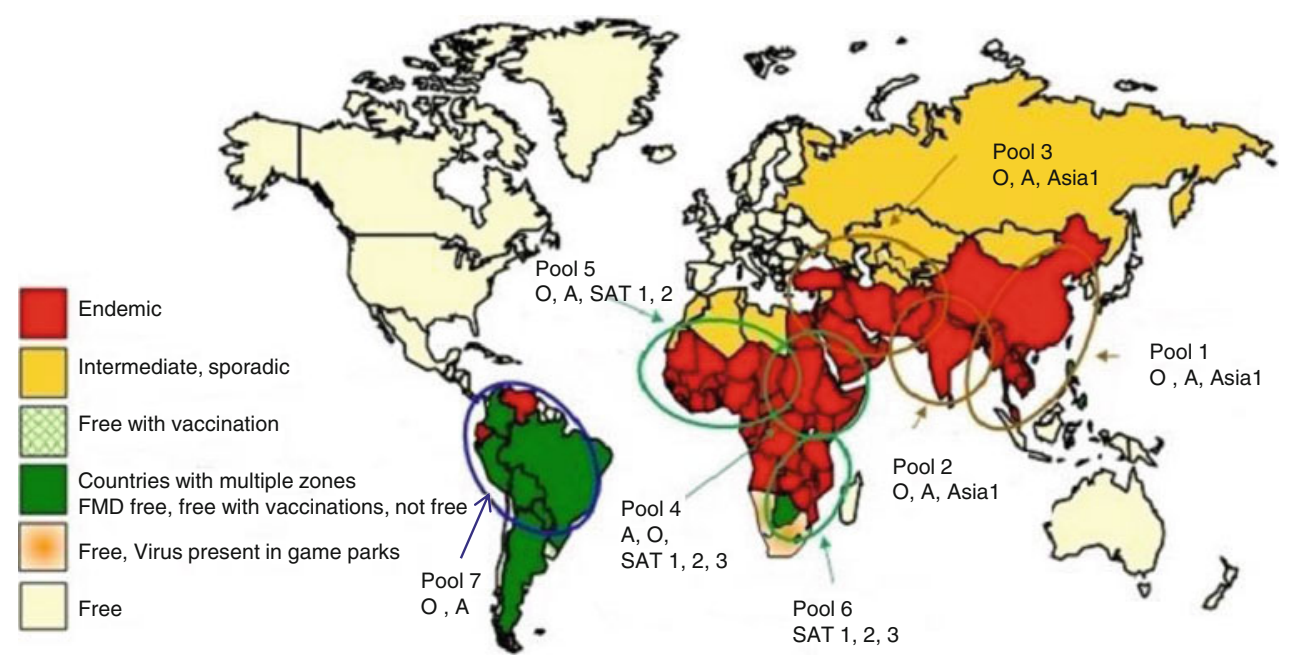

Fig. 1 The conjectured status of FMD in 2010 showing approximate distribution of regional virus pools (Annual OIE/FAO FMD Reference Laboratory Network Report, 2010). The global pool of FMD viruses can be subdivided into seven 'regional pools' (Pool 1-Eastern Asia; Pool 2-Southern Asia; Pool 3-Euro-Asia; Pool 4-Eastern Africa;

and from Canada in 1952. In today's scenario, for efficient control of FMD, regular vaccination and restriction of the movement of infected animal products are crucial [47]. Stamping out of animals is not practicable in many countries including India. Prophylactic vaccination is required in endemic countries. In FMD free countries, emergency vaccination (vaccinate-to-live) with culling of infected animals may be practiced. The "Vaccinate-to-kill" policy, where all vaccinated animals are killed after the outbreak has ceased, was put to question following 2001 outbreak in the Netherlands. FMD free countries may opt for vaccinate-to-live policy in case of any exigency. Now, OIE is also recognizing FMD free zones maintained by vaccination within an endemic country. Currently, 65 countries are free from FMD without vaccination and 1 country (Uruguay) with vaccination. Besides, 14 zones have been declared free for FMD with either vaccination or no vaccination by OIE. In Asia, Brunei Darussalam, Indonesia and Singapore are recognized by OIE as FMD free countries without vaccination. Zones recognized by OIE as FMD free without vaccination are Sabah and Sarawak in Malaysia, and the islands of Mindanao, Visayas, Palawan and Masbate in the Philippines.

\section{Control Measures in South America}

Following the rapid spread of FMD in the American continent during the first half of the 20th century and closure of English and USA markets for livestock products from South America, a Pan-American FMD center (PANAFTOSA) was created in 1951 in Rio de Janeiro, Brazil to assist and contribute to the control of FMD in the region
Pool 5-Western Africa; Pool 6-Southern Africa; Pool 7-South America) in which genetically and antigenically distinctive virus strains tend to occur within a defined region. Periodically, viruses spread between pools and to free regions

[10]. Now several countries/zones in the South America are free from FMD with or without vaccination. The hemispheric plan for FMD eradication (PHEFA) was implemented in 1988 and as a result Chile became FMD free (2007) without vaccination. Argentina, Paraguay, Uruguay and the states of Rio Grande do Sul and Santa Catarina in Brazil are also recognized by the OIE to be FMD free, with vaccination. Clinical FMD has been absent from Uruguay since August 2001; from Argentina since January 2002 and from Rio Grande do Sul, Brazil since July 2001. The use of continental surveillance system (PHEFA, PANAFTOSA) has been the main strategy for achieving control and eradication of FMD in South America. The widespread use of oil-adjuvant vaccines and the development of strategic schemes for coverage were instrumental in decreasing clinical disease first and then controlling FMD to a point that eradication could be achieved. To prevent reintroduction of FMD virus into free areas, their national programmes stress on primary prevention activities with regional approaches and vaccination campaigns based on homogeneous coverage and timing, especially along international borders [60].

\section{Control Measures in European Union}

The European Commission for the Control of FMD (EUFMD) was established in 1954 as a special body by Food and Agriculture Organization (FAO) of the United Nations to combat FMD in Europe. The role of the Commission is to co-ordinate the activities of the member states in controlling and preventing FMD. It provides support to member countries in FMD surveillance and circulates 
information on the FMD situation, especially when there is a threat to Europe, and provides advice on all aspects of FMD prevention and control to the member countries on request. It also organizes training/workshops in specific laboratory on epidemiological techniques.

\section{Control Measures in South East Asia}

Control and eradication of the disease has been facilitated in regions of the world through inter-country participation, as the disease is of trans-boundary nature. South East Asia Foot-and-mouth disease (SEA-FMD) campaign was launched in 1997 to coordinate sub-regional control of FMD. In 2010, China joined the campaign and it was renamed as South East Asia and China Foot and Mouth Disease (SEAC-FMD) campaign. The main strategy was the implementation of a progressive zoning approach to ensure effective use of limited resources from the donors and national governments. The campaign has established Epidemiology Network (EpiNet) and a Laboratory Network (LabNet) to provide technical support to enhance member countries' capacity for effective surveillance and diagnosis. South Asian control campaign is likely to start soon with inter-country participation in the South Asian Association for Regional Cooperation (SAARC) region. FMD control campaign has already started in India since 2003-2004.

\section{FMD Status in India}

FMD is endemic in India and has been reported throughout the year in almost all parts of the country. At present, the disease occurrence, severity of the clinical disease and number of outbreaks have progressively and substantially declined in areas under regular vaccination mostly under FMD control programme and partly under ASCAD (Assistance to States for
Control of Animal Diseases) and RKVY (Rashtriya Krishi Vikas Yojona) of the Government of India. The disease situation in India is complicated due to the plurality of the circulating virus strains in serotypes $\mathrm{O}$, A and Asia 1, unrestricted movement of animals from infected areas and in apparent infection in small ruminants. Among the serotypes, type $\mathrm{O}$ is the most prevalent one and accounts for $83-93 \%$ of the outbreaks followed by Asia 1 (3-10\%) and A (3-6.5\%). Serotype $\mathrm{C}$ has not been reported in the country since 1995 . As per the National FMD Sero-surveillance study, the average prevalence of FMD infection in bovine population based on anti$3 \mathrm{AB}$ NSP ELISA was found to be $\sim 27.5 \%$, whereas, in goats, sheep and pig the prevalence has been found to be 20.0, 15.0 and $2.0 \%$, respectively. Percentage of FMD prevalence rate in different states of India is depicted in Fig. 2. Since a single NSP based assay could not always detect infection, use of two NSP assays is preferred. For this a profiling ELISA was developed using a panel of recombinant NSPs $2 \mathrm{C}, 3 \mathrm{D}, 3 \mathrm{AB}$ and $3 \mathrm{ABC}$ as an integrated NSP-serology system which has the potential to be employed as an easy-to-perform foolproof confirmatory assay. Besides, it can be also noted that the calves administered with either of the two commercial vaccines available in India every six months as practiced in the field, did not reveal any detectable $3 \mathrm{AB}-\mathrm{Ab}$ response even up to the fifth booster [42, 43].

\section{Molecular Epidemiology of FMD in India}

Serotype O FMD virus isolates from India group in seven sub-lineages, namely Branch A, B, C-I, CII, Pan Asia I, Pan Asia II and 'Ind2001' under ME-SA (Middle EastSouth Asia) topotype (Fig. 3). The Pan Asia II lineage emerged in 2003 and since then is causing outbreaks along with parent Pan Asia I in the country. Lineage 'Ind2001' first identified in the year 2001, remerged in 2008 and is

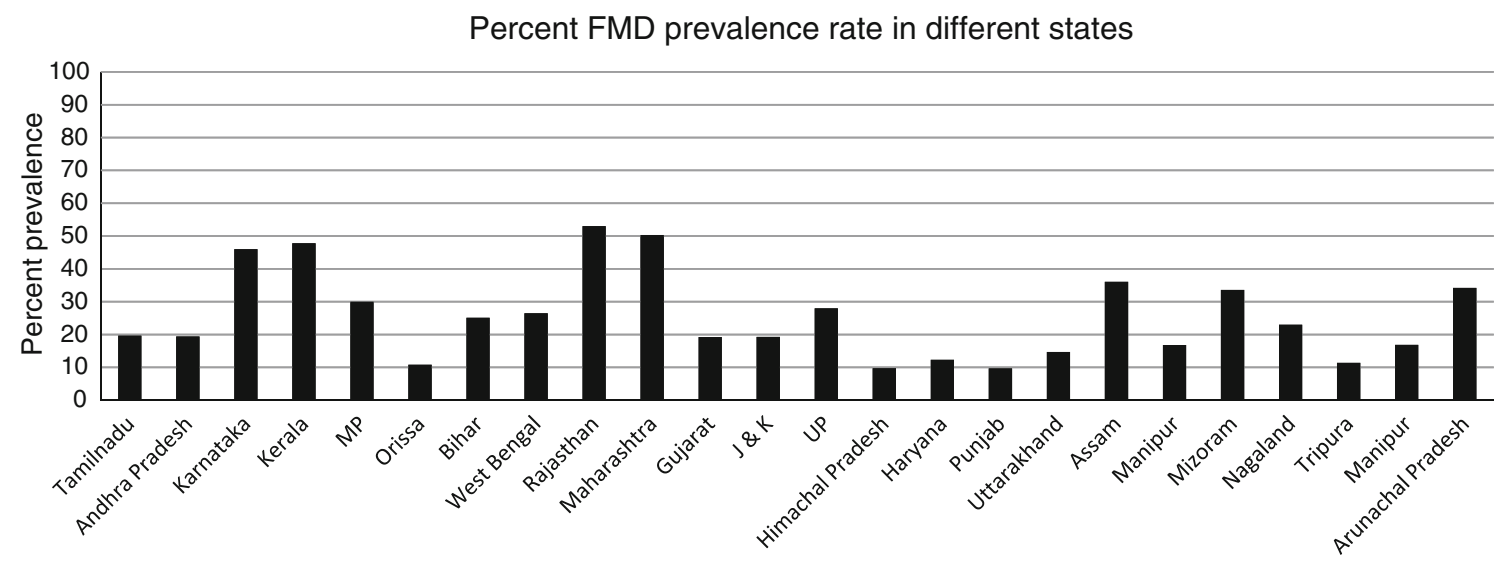

Fig. 2 Percent FMD prevalence rate in different states as estimated in anti-3AB3 DIVA (Differentiation of infected from vaccinated animals) ELISA during 2008-2010. Average prevalence of FMD infection in bovine population in the country was found to be $\sim 27.5 \%$ 
co-circulating along with Pan Asia lineages since then. Currently three lineages viz. 'Ind2001', Pan Asia I and Pan Asia II are responsible for type $\mathrm{O}$ outbreaks in the country. Though the current serotype $\mathrm{O}$ vaccine strain (IND R2/ 1975) is not genetically identical to the circulating field strains, it continues to antigenically cover the outbreak strains. Almost all cases of outbreaks investigated involving serotype $\mathrm{O}$ have been due to low level of protective antibodies in the animals. This vaccine strain in the trivalent FMD vaccine has been able to substantially and progressively reduce the circulation of serotype $\mathrm{O}$ virus in regularly vaccinated areas. In case of serotype A, four genotypes [genotypes I (2), IV (10), VI (16) and VII (18)] have been documented out of 26 global genotypes (Fig. 4) $[42,43]$. Genotypes 2 (Euro-South Asian topotype) and 10 (Asia topotype) of serotype A were recorded before 1990 and no longer seem to exist in India. Endemic co-circulation of two (16 and 18) genotypes since 1990 has been observed with the recent dominance of genotype 18 in the field. The current serotype A vaccine strain (IND 40/2000) belongs to genotype 18 (earlier classified as genotype VII). The isolates belonging to genotypes 16 and 18 are not only genetically, but also antigenically divergent with poor inter-genotypic antigenic coverage between them. Molecular phylogeny based on VP1 encoding region of serotype Asial virus isolates has established circulation of three prominent lineages (lineages B, C and D) in India [59] (Fig. 5) The lineage $B$ which includes the vaccine strain IND 63/1972 has 210 amino acids in VP1 and this lineage never appeared after the year 2000. The lineage $C$ which was prominently circulating in India during the period 1993-2001 has an extra amino acid at position 44 of VP1. Lineage D, with-in the lineage C appeared in 2001 and it outnumbered the parent lineage in terms of field outbreaks. Lineage $\mathrm{C}$ has been responsible for all Asial outbreaks in the country since 2005 . The serotype Asial vaccine strain IND 63/1972 currently in use for vaccine production is continuing to provide optimum antigenic coverage for the circulating field strains.

\section{Road Map for Control and Prevention of FMD in India}

In the wake of global eradication of rinderpest and the current effort to contain the spread of avian influenza, the progressive world-wide control of FMD must be regarded as a major contribution to the international public good [55]. Control of FMD is relevant, for protecting the livestock industries in developed countries and for livelihoods and income generation in the developing countries, where FMD is endemic. Progressive risk reduction of FMD can help in progressive market access of livestock commodities from developing countries. National veterinary services and disease surveillance are important arms of successful FMD control programme(s).

The strategy for the progressive control of FMD in the endemic settings should be based on a seven stage process [55] within a period of about 30 years, namely: (1) assessing and defining National FMD status; (2) undertaking vaccination and movement control; (3) suppressing virus transmission to achieve absence of clinical disease; (4) achieving freedom from FMD with vaccination in accordance with the OIE standards; (5) achieving freedom from FMD without vaccination in accordance with the OIE standards; (6) extending FMD free zones; and (7) maintaining FMD freedom. In the context of India, where as of now there is uncontrolled animal movement across the country, the Progressive control pathway (PCP) will require more time. Once the disease is under progressive control, there has to be introduction of risk reduction measures to avoid the risk of disease spread.

Following issues need to be addressed for the control of FMD with the final aim of eradication in a time frame.

\section{Establishment of National FMD Commission}

In order to more effectively implement and monitor the control programme and achieve zoning of the disease (initially with vaccination) in the country in a time frame, we need to have in place a National FMD Commission to coordinate all the organizations associated with FMD control programme including quality assurance of vaccines. The organizations such as Indian Council of Agricultural Research (ICAR), DAHD\&F, State Departments of Animal Husbandry, Vaccine manufacturers, Farmer's Organizations, Dairy Cooperatives and all other agencies associated directly or indirectly with the livestock industry have to actively participate under this Commission.

Vaccine and Vaccination

Timing of vaccination should be uniform for best results. Availability of quality vaccine as per requirement is utmost important for the success of control programme. Quality vaccine with high potency is required to cover wide antigenic spectrum and elicit longer duration of immunity (9-12 months). Options for using trivalent, bivalent and monovalent vaccines based on epidemiological data should be kept open. Use of monovalent vaccines where particular serotype is prevalent for a long time, will reduce the cost of the operation. Maintenance of cold chain is important as immunogenicity of antigen is lost by exposure to high temperature, and repeated freezing and thawing. Susceptible livestock populations, primarily cattle and buffalo, should be covered under vaccination campaign. At some point of time, 
Fig. 3 Phylogenetic tree depicting genetic relationship among type $\mathrm{O}$ isolates at VP1 coding region. The tree was constructed by the alignment of full-length nucleotide sequences of VP1 region of FMDV serotype $\mathrm{O}$ isolates. The sequences were aligned in MEGA5 using the Clustal W and the tree was constructed by Neighbor-joining method. The horizontal distances are proportional to genetic distance amongst different FMDVs; vertical distances are arbitrary. The numbers at each node represent the percentage boot strap scores (10,000 replicates). Currently used vaccine strain is underlined. The isolates from different states could be placed in three major lineages designated 'Ind2001' and Pan Asia. Within parent Pan Asia lineage, a divergent Pan Asia II sub-lineage emerged in 2003
Phylogenetic tree depicting genetic relationship among type $\mathrm{O}$ isolates

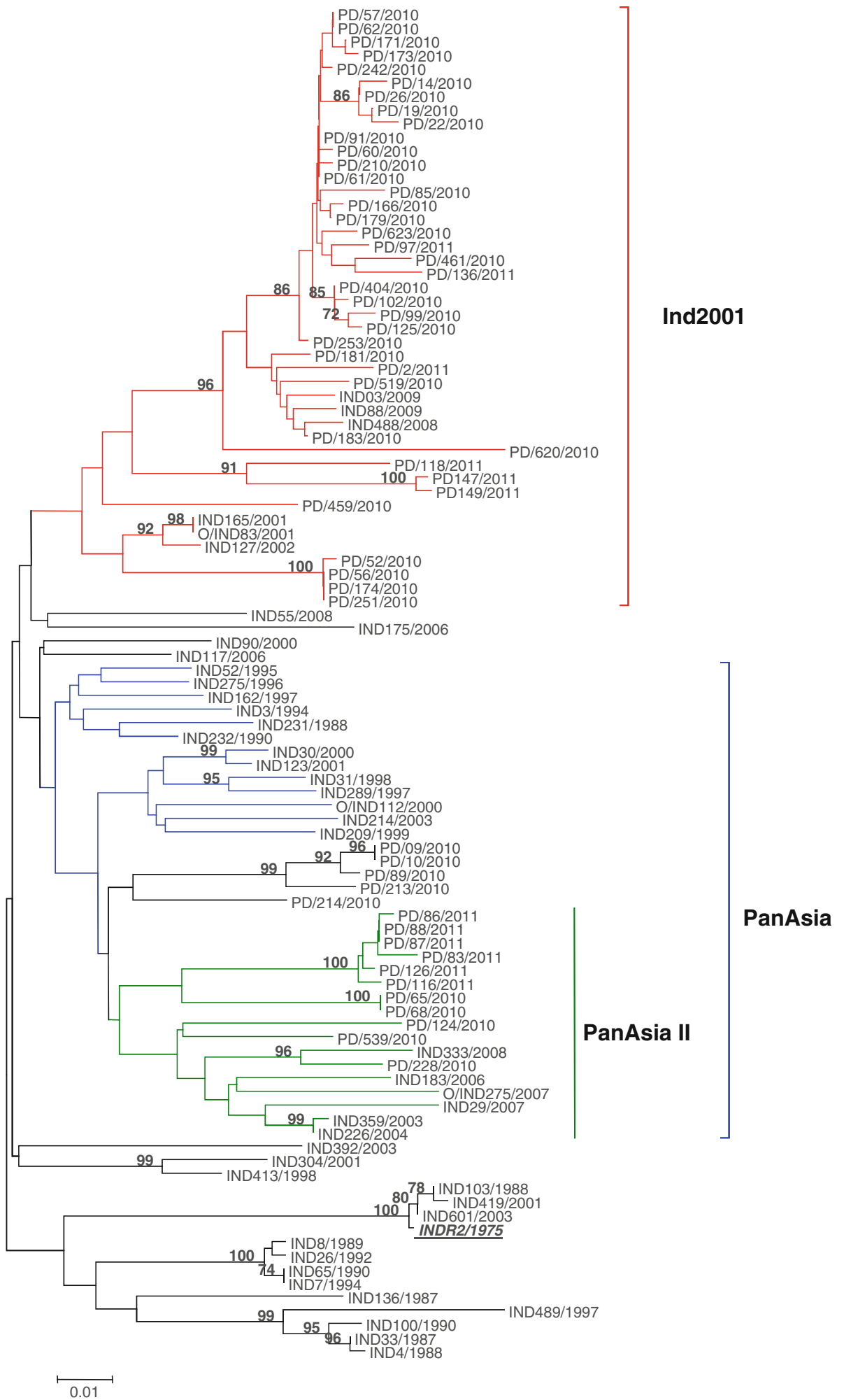

sheep, goat and pigs should be vaccinated with lower dose of vaccine. The demand for FMD vaccine will go up considerably once the control programme is expanded to cover the entire country. Currently, there are 4 FMD vaccine manufacturers in the country viz; Indian Immunologicals Limited, Intervet Limited, Biovet Limited and Brilliant Industries with a total installation capacity of about 390 million trivalent doses annually. Resources and skills are 
Fig. 4 Phylogenetic tree depicting genetic relationship among type $\mathrm{A}$ isolates at VP1 coding region. The tree was constructed by the alignment of full-length nucleotide sequences of VP1 region of FMDV serotype A isolates. The sequences were aligned in MEGA5 using the Clustal W and the tree was constructed by Neighbor-joining method. The horizontal distances are proportional to genetic distance amongst different FMDVs; vertical distances are arbitrary. The numbers at each node represent the percentage boot strap scores $(10,000$ replicates). The isolates from India were placed in four genotypes $(2,10$, 16 and 18) showing more than $15 \%$ nt. divergence among them. Isolates of genotype 18 exclusively dominates type A outbreaks in the country since 2001 and currently used vaccine strain belonged to this genotype
Phylogenetic tree depicting genetic relationship among type $\mathrm{A}$ isolates

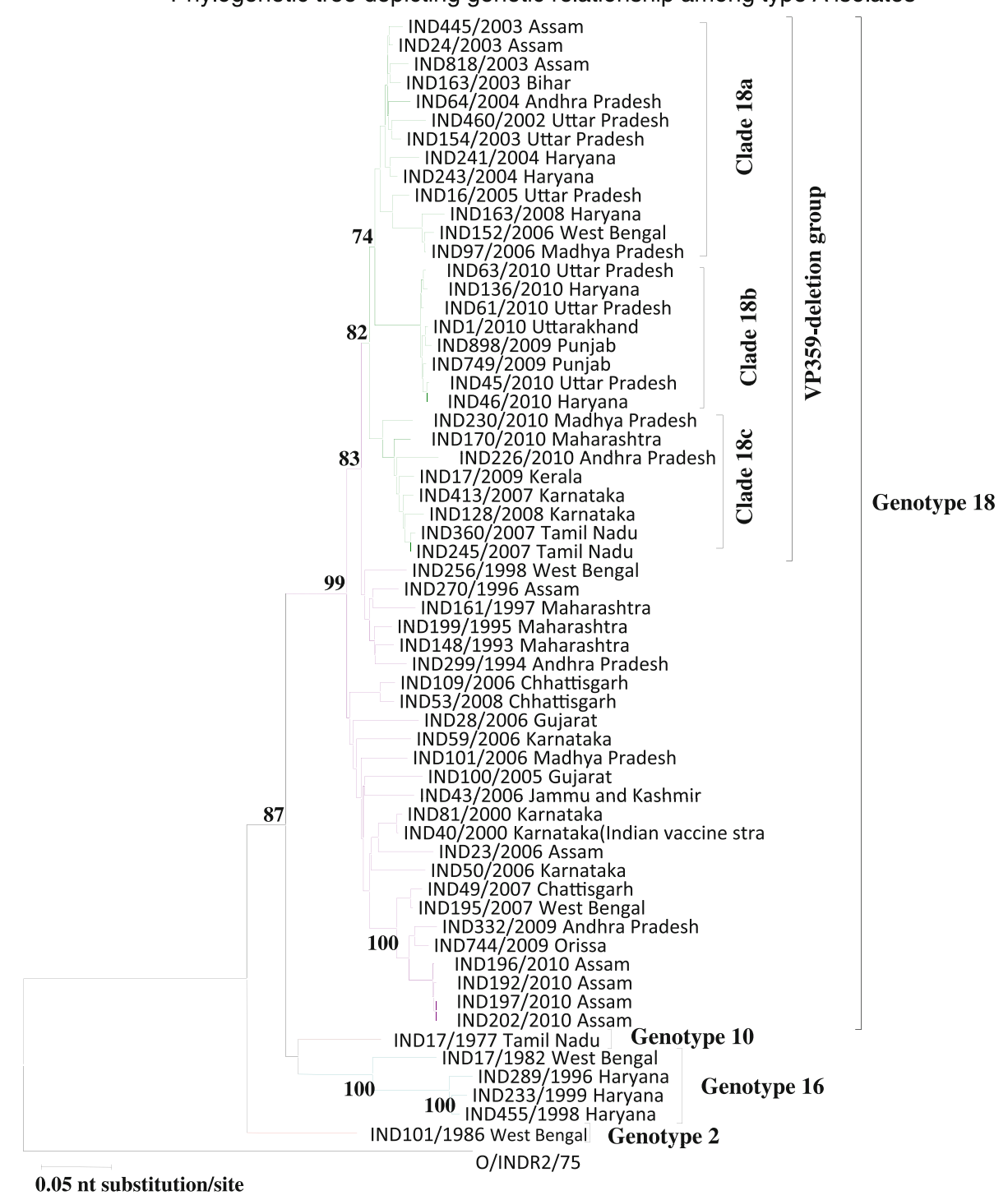

available in India to meet the total demand of the country for FMD vaccine.

The current vaccine is used at a dose of $3 \mathrm{PD}_{50}$ (if the vaccine is diluted to $1 / 3$, it is likely to protect $50 \%$ of the vaccinated cattle challenged by intra-dermolingual route using $10,000 \mathrm{ID}_{50}$ ) per animal, and is able to provide protective immunity only up to $4-5$ months. Such short duration of immunity not only poses constant threat to the vaccinated animals (if not revaccinated in time) but also establishes sub-clinical (carrier status) infections. To mitigate all such effects, it is required that the antigen payload in the vaccine is increased to at least to 6-8 $\mathrm{PD}_{50}$. Having a higher antigen mass per dose of vaccine will help in obtaining faster and higher duration of immunity following vaccination [19]. Though, this will increase the cost of the vaccine, it will be advantageous in longer term as disease control and eradication time will be reduced.

Here it is pertinent to think for test system(s) alternative to the in vivo challenge test in cattle (to determine $\mathrm{PD}_{50}$ ) based on correlation between serum antibody titers in vaccinated cattle and protection against infection. It has been reported that this indirect potency measurement is at least as precise as the in vivo challenge test, and can be standardized to 'antigen $\mathrm{PD}_{50}$ ' values [31]. Development of such an assay system need to be done in the country in order to avoid animal ethics problem, biosecurity and biosafety concerns, and problem in the disposal of infected cattle when challenge method is used for potency testing of the vaccine.

Free FMD vaccination for border traders would encourage more legal animal traffic. Identification number 
Fig. 5 Phylogenetic tree depicting genetic relationship among type Asial isolates at VP1 coding region. The tree was constructed by the alignment of full-length nucleotide sequences of VP1 region of FMDV serotype Asia1 isolates. The sequences were aligned in MEGA5 using the Clustal W and the tree was constructed by Neighbor-joining method. The horizontal distances are proportional to genetic distance amongst different FMDVs; vertical distances are arbitrary. The numbers at each node represent the percentage boot strap scores (10,000 replicates).The isolates from India were placed in three lineages designated $\mathrm{B}, \mathrm{C}$ and $\mathrm{D}$. Indian vaccine strain (IND63/ 1972) belonged to lineage B. Lineage $\mathrm{C}$ is exclusively responsible for all type Asia1 outbreaks in the country since 2005
Phylogenetic tree depicting genetic relationship among type Asia1 isolates

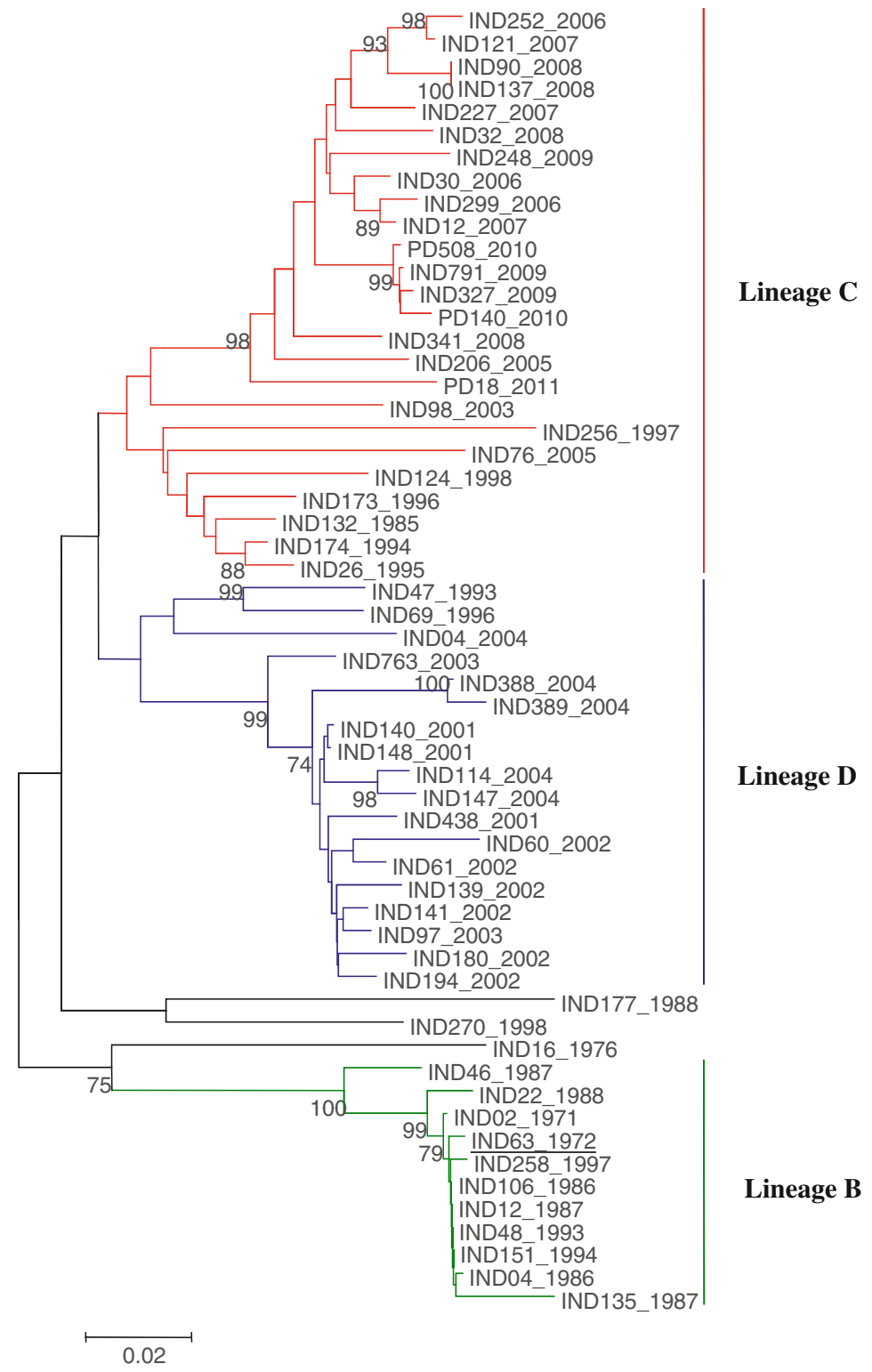

should be made mandatory for all cattle, buffalo, sheep, goats and pigs. It will help in maintaining health records including history of vaccination(s) and controlling/monitoring their movement within the country and at international boundaries.

\section{Improved Machinery for Surveillance}

As the disease is on progressive decline and virus circulation has been hindered in regularly vaccinated areas and zoning is at sight, the ongoing surveillance has to be strengthened using the tools of ICT (Information \& Communication Technology) and GIS (Geographical Information System) for timely covering the entire country on a regular basis. Population surveillance for antibody to structural and non structural proteins of FMDV will be required to be strengthened to monitor herd immunity, virus circulation and clearance from time to time as the vaccination based control programme continues. Establishment of National information network for FMD is a must to monitor and map disease occurrence in real-time. Surveillance in susceptible captive wild animals through collaboration with Central Zoo Authority need to be carried out as these animals may play vital role in maintaining the virus in some areas.

\section{Establishment of Epidemiology Network Units} at Porous International Borders

Prevention of uncontrolled movement/illegal trafficking of animals at the international borders is a must for any 
country to successfully control FMD. Since the disease is endemic in the subcontinent (South Asia) and India shares international boundaries with some countries (more importantly Pakistan, Nepal, Bangladesh and Bhutan), movement of virus across the borders needs to be monitored. Establishment of epidemiology network units at such borders will not only help in quick diagnosis of the suspected cases but will also keep a constant vigil on disease occurrence in nearby areas.

Improving communication between member countries in the SAARC region to mutually convey each other about the disease occurrence on fortnightly basis is essential as the disease is endemic in the sub-region and trans-boundary in nature. This needs to be facilitated by FAO/OIE with the involvement of DAHD\&F and ICAR. The sharing of information and coordination of activities between countries will minimize risks of disease establishment and spread.

\section{Control of Animal Movement}

Animal movement has been considered the predominant cause of FMD in vaccinated zones. Given the economic value of the livestock trade, there is considerable animal movement within the country and in the SAARC region. The directions and extent of animal movement is influenced by socio-economic circumstances in the region. Recourse to legislation, check points, quarantine and the permit system are required to control and manage animal movement that will reduce the risk of spread of the disease. The strategy for more effective control of animal movement should be economical and efficient in improving the efficiency of legal animal movement.

\section{Biosafety and Biosecurity}

Biosafety and biosecurity are to be achieved in a time frame (before 2015) for safe handling and storage of field virus strains, so that risk of virus escape from the laboratory and vaccine manufacturers is minimized. Appropriate biosafety laboratory facilities will be required to complete stage 3 before proceeding to stage 4 of the PCP for control of the disease.

\section{Zoo Sanitary Measure}

Besides vaccination, effective application of zoo-sanitary measures is very important. This will help in prevention of virus entry into vaccinated zone/district/region, control of virus spread and speedy elimination of virus from outbreak area.

\section{FMD Control Programme in India}

FMD control programme $(\mathrm{CP})$ in India is envisaged as per the FAO's PCP having following seven stages:

\begin{tabular}{|c|c|}
\hline $\begin{array}{c}\text { Stage } \\
0\end{array}$ & FMD risk not controlled and no reliable information \\
\hline $\begin{array}{c}\text { Stage } \\
1\end{array}$ & $\begin{array}{l}\text { Uunderstanding of the epidemiology of FMD in the country } \\
\text { and develop a risk based approach to reduce the impact of } \\
\text { FMD }\end{array}$ \\
\hline $\begin{array}{c}\text { Stage } \\
2\end{array}$ & $\begin{array}{l}\text { A strategic FMD control plan that has the aim of reducing the } \\
\text { impact of FMD in at least one zone or sector is developed }\end{array}$ \\
\hline $\begin{array}{l}\text { Stage } \\
3\end{array}$ & $\begin{array}{l}\text { Implementation of control strategy that has the aim of } \\
\text { eliminating FMD from at least a zone of the country }\end{array}$ \\
\hline $\begin{array}{l}\text { Stage } \\
4\end{array}$ & $\begin{array}{l}\text { Maintain zero circulation or incursions. It should have the } \\
\text { evidence that FMD is not occurring endemically within the } \\
\text { zone or country }\end{array}$ \\
\hline $\begin{array}{c}\text { Stage } \\
5\end{array}$ & $\begin{array}{l}\text { Maintain zero circulation or incursions and withdraw } \\
\text { vaccinations. Once, the OIE requirements for recognition of } \\
\text { 'free with vaccination' are fulfilled, a dossier has to be } \\
\text { submitted to OIE for recognition of this status }\end{array}$ \\
\hline $\begin{array}{c}\text { Stage } \\
6\end{array}$ & $\begin{array}{l}\text { Free without vaccinations. Application to OIE for recognition } \\
\text { of "free without vaccination" status (zone or whole } \\
\text { country) }\end{array}$ \\
\hline
\end{tabular}

The control programme (FMDCP) was launched in India in 2003-2004 in 54 districts selected in 2008 states of the country covering 30 million cattle and buffalo population with an objective of creating FMD free zones and then expanding these zones to cover the entire country. The basic approach is to vaccinate all cattle and buffalo every 6 months. Due to initial success, additional 167 districts (another 80-90 million cattle and buffalo) have been included under the programme in 2010-2011 (Fig. 6). Currently, this programme includes 221 districts of the country covering states of Southern peninsula (Kerala, Tamil Nadu, Puducheri, Karnataka and Andhra Pradesh), Maharashtra, Goa, Daman and Diu, Gujarat, Punjab, Haryana, Delhi, Dadra and Nagar Haveli, Andaman \& Nicobar Islands, Lakshadweep and 16 districts in Uttar Pradesh, and targeting $\sim 110$ million cattle and buffalo. The target of this progressive zoning approach is that all animals are vaccinated twice a year ( 6 monthly) and certain number of random serum samples are tested in each district for pre and post vaccination SP-antibody level by a liquid phase blocking (LPB) ELISA (LPB-ELISA) and concurrent disease surveillance. There is no scope for slaughter of affected and in-contact cattle. Gradual increase in protective antibody response was observed subsequent to phase 1 vaccination. After phase X (2009-2010) vaccination, 87.4, 74.7 and $76.7 \%$ of animals tested were having protective antibody level against serotypes $\mathrm{O}, \mathrm{A}$ and Asia-1, respectively, in post-vaccination serum samples (Fig. 7). These results 
Fig. 6 The districts of India covered under FMD-CP. Fifty four districts in which control programme started in 2003-2004 (Stage 3) are marked red (dark). One hundred and sixty seven districts in which the control programme started in 2010-2011 (Stage 2) are marked green (grey). (Color figure online)

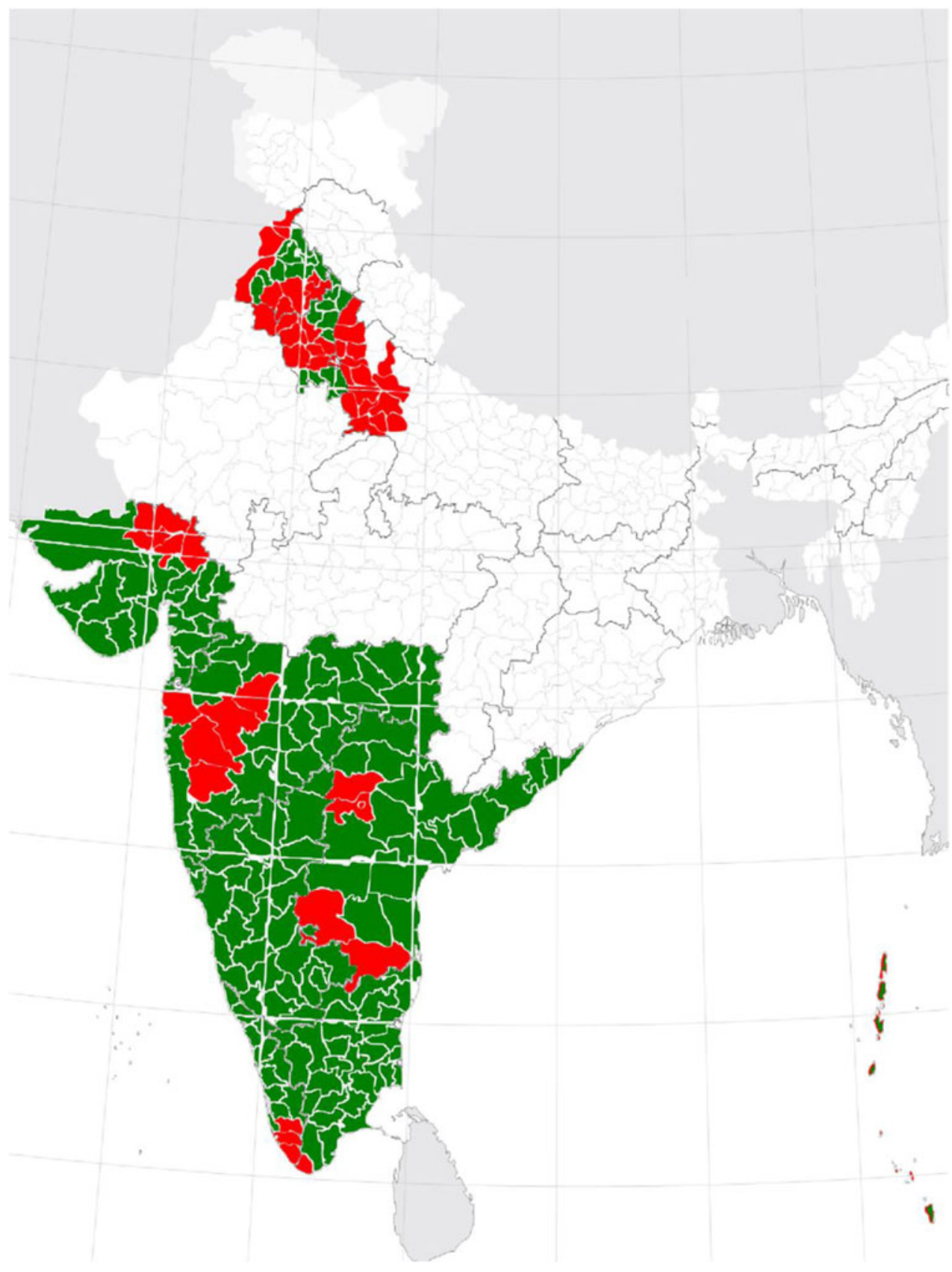

indicate strong build up of immunity. The herd immunity has progressively increased with minor aberrations that speak for positive impact of vaccination for last 6-7 years. Number of outbreaks recorded in the country during last 5 years is shown in Table 1 . As of today, it has been observed that severity of clinical sickness has been reduced substantially and number of FMD cases/outbreaks have dropped in different parts of the country as estimated by real-time monitoring and surveillance. The 3AB3 DIVA test shows reduced circulation of the virus in regularly vaccinated areas compared to other areas of the country. Few sporadic cases of FMD in some vaccinated populations/ districts affecting a few animals were recorded. This may be due to unrestricted animal movement from the neighboring unvaccinated districts/states. Nevertheless, infection could not spread due to surrounding herd immunity.

Information generated and lessons learnt from the FMDCP operation in the 54 districts indicate that:

1. Regular 6 monthly vaccinations have resulted in progressive build up of herd immunity and decline in the occurrence of the disease.

2. Delay in re-vaccination causes drop in herd immunity level, thereby posing risk to the animals. 

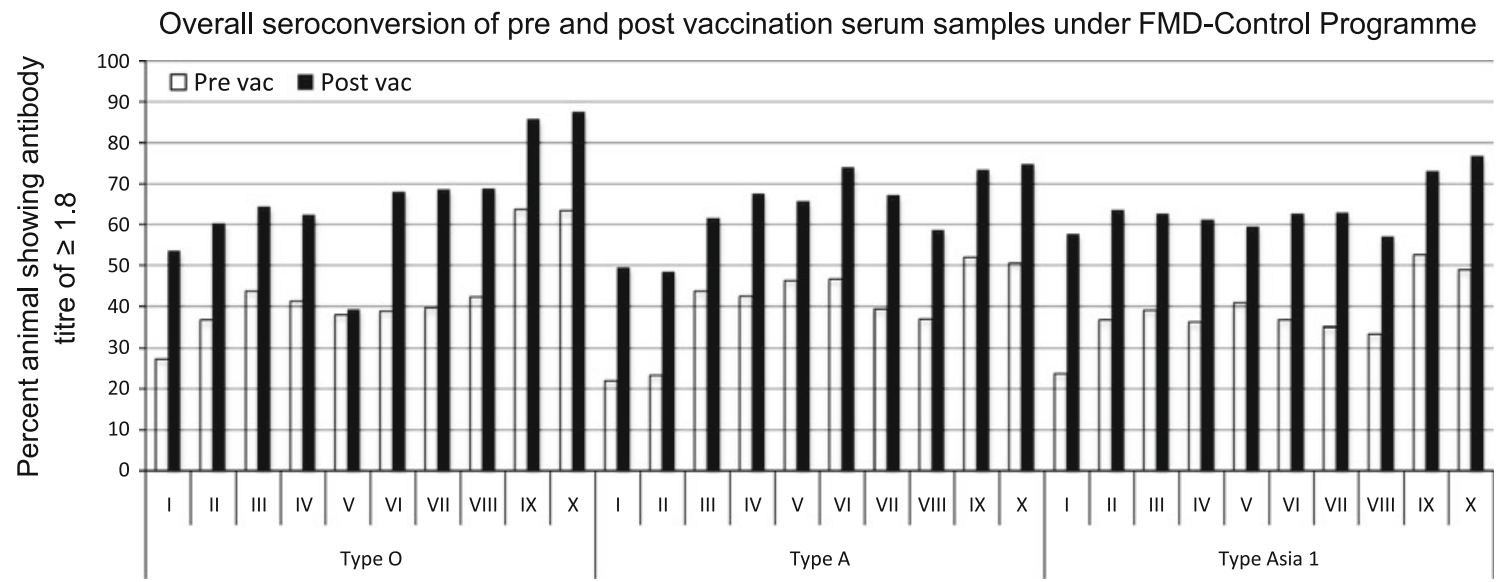

Fig. 7 Overall seroconversion of pre and post vaccination serum samples under FMD-control programme from phase I to X. Empty bar indicates pre-vaccination antibody titre and filled bar indicates post vaccination titer against serotype $\mathrm{O}, \mathrm{A}$ and Asial

Table 1 Number of confirmed FMD outbreaks/cases in different geographical regions of the country during 2006-2007 to 2010-2011

Year South North Central West East North East Total

\begin{tabular}{lrrrrrrr}
\hline $2006-2007$ & 224 & 7 & 23 & 29 & 431 & 64 & 778 \\
$2007-2008$ & 445 & 20 & 35 & 31 & 258 & 88 & 877 \\
$2008-2009$ & 64 & 18 & 33 & 16 & 66 & 43 & 240 \\
$2009-2010$ & 59 & 55 & 20 & 24 & 365 & 75 & 598 \\
$2010-2011$ & 51 & 9 & 29 & 18 & 29 & 40 & 176 \\
Total & 843 & 109 & 140 & 118 & 1149 & 310 & 2669 \\
\hline
\end{tabular}

Source All India coordinated research project (AICRP) for epidemiological studies on foot-and-mouth disease, Mukteswar-Kumaon, Uttarakhand, India

3. Density and timing of vaccination have to be made uniform in the FMDCP areas. Vaccination timing has to be synchronized at the district and state level.

4. Quality of FMD vaccine being used should be ascertained by an independent National Agency.

As on date, the 54 districts covered in the first phase of FMDCP are in "stage 3" and the newly added 167 districts are in "stage 2" of PCP. The disease is under control in some northern states (stage 3), and it is expected that by 2018, the quadrangle comprising of the states of Himachal Pradesh, Delhi, Haryana and Punjab will be Disease Free zone (DFZ) with vaccination (stage 4 ). At this stage, it is required that the adjacent areas of Uttar Pradesh and Rajasthan are put under strict surveillance and a $5-10 \mathrm{~km}$ radius vaccinated ring is maintained to prevent virus incursion.

At the current success rate, it is expected that by 2018 , the disease situation in entire southern peninsula (Kerala, Tamil Nadu, Puducheri, Karnataka and Andhra Pradesh) will be under control (stage 3) with a herd immunity of $>85 \%$. By 2025 , it is anticipated that the southern peninsula will be disease free with vaccination (stage 4) when it will be monitored for the next 05 years. Threat of virus incursion into the southern peninsula will be from the states of Orissa and Chhattisgarh; and it is expected that by 2015-2017 these two states will also be covered under FMDCP. It is expected that by 2025 , most parts of the country will be in stage 3, southern peninsula will be in stage 4 (free with vaccination), and the northern quadrangle (mentioned above) will enter stage 5 of PCP.

To conclude, (1) Epidemiological data required for control and final eradication of FMD is being generated in India in real-time, and the country is competent in companion diagnostics required for the control programme, (2) At the current success rate of the control programme in India, it is expected that zoning of the disease will be achieved by 2025 , thereby enabling India to enter international livestock product market and improve global food security and rural livelihood.

Acknowledgments The authors sincerely thank Indian Council of Agricultural Research for providing necessary facilities to carry out the work at PD-FMD, Mukteswar.

\section{References}

1. Abu Elzein EME, Crowther JR (1978) Enzyme labelled immunosorbent assay techniques in FMDV research. J Hyg (London) 80:391-399

2. Aidaros HA (2002) Regional status and approaches to control and eradication of foot and mouth disease in the Middle East and North Africa. Sci Tech Rev OIE 21(3):451-458

3. Ansell DM, Samuel AR, Carpenter WC, Knowles NJ (1994) Genetic relationships between foot-and-mouth disease type Asia 1 viruses. Epidemiol Infect 112:213-224

4. Araujo JP, Montassier HJ, Pinto AA (2002) Extensive antigenic and genetic variation among foot-and-mouth disease type A viruses isolated from the 1994 and 1995 foci in Sao Paulo, Brazil. Vet Microbiol 84:15-27

5. Bachrach HL (1968) Foot-and-mouth disease virus. Annu Rev Microbiol 22:201-244 
6. Bastos ADS, Haydon DT, Forsberg R, Knowles NJ, Anderson EC, Bengis RG, Nel LH, Thomson GR (2001) Genetic heterogeneity of SAT-1 type foot-and-mouth disease viruses in southern Africa. Arch Virol 146:1537-1551

7. Bastos ADS, Haydon DT, Sangare O, Boshoff CI, Edrich JL, Thomson GR (2003) The implications of viral diversity within the SAT-2 serotype for control of foot-and-mouth disease in subSaharan Africa. J Gen Virol 84:1595-1606

8. Baxt B, Morgan DO, Robertson BH, Timpone CA (1984) Epitopes on foot and mouth disease virus outer capsid protein VP1 involved in neutralization and cell attachment. J Virol 51: 298-305

9. Beard CW, Mason PW (2000) Genetic determinants of altered virulence of Taiwanese foot-and-mouth disease virus. J Virol 74: 987-991

10. Bergmann IE, Malirat V, Falczuk AJ (2005) Evolving perception on the benefits of vaccination as foot-and-mouth disease control policy: contributions of South America. Expert Rev Vaccin 4: 903-913

11. Bhattacharya S, Pattnaik B, Venkataramanan R (1996) Development and application of a sandwich enzyme-linked immunosorbent assay (ELISA) for type identification of foot-andmouth-disease (FMD) virus in direct field materials. Ind J Anim Sci 66:1201-1209

12. Bolwell C, Clarke BE, Parry NR, Ouldridge EJ, Brown F, Rowlands DJ (1989) Epitope mapping of foot-and-mouth disease virus with neutralizing monoclonal antibodies. J Gen Virol 70:59-68

13. Brooksby JB (1952) The techniques of complement fixation in foot-and-mouth disease research. A.R.C. Rep., Series 12, H.M.S.O., London

14. Brooksby JB (1958) The virus of foot-and-mouth disease. Adv Virus Res 5:1-37

15. Brown F (2003) The history of research in foot-and-mouth disease. Virus Res 91:3-7

16. Brown F, Hyslop NS, Crick J, Morrow AW (1963) The use of acetylethyleneimine in the production of inactivated foot-andmouth disease vaccines. J Hyg 61:337-344

17. Capstick PB, Telling RC, Chapman WG, Stewart DL (1962) Growth of a cloned strain of hamster kidney cells in suspended cultures and their susceptibility to the virus of foot-and-mouth disease. Nature 195:1163-1164

18. Condy JB, Hedger RS, Hamblin C, Barnett ITR (1985) The duration of the foot-and-mouth disease carrier state in African buffalo (i) in the individual animal and (ii) in a free-living herd. Comp Immunol Microbiol Infect Dis 8:259-265

19. Cox SJ, Parida S, Voyce C, Reid SM, Hamblin PA, Hutchings G (2007) Further evaluation of higher potency vaccines for early protection of cattle against FMDV direct contact challenge. Vaccine 25:7687-7695

20. Crowther JR, Farias S, Carpenter WC, Samuel AR (1993) Identification of a fifth neutralizable site on type $\mathrm{O}$ foot-andmouth disease virus following characterization of single and quintuple monoclonal antibody escape mutants. J Gen Virol 74:1547-1553

21. Darbyshire JH, Hedger RS, Arrowsmith EM (1972) Comparative complement-fixation studies with subtype strains of foot-andmouth disease virus. J Hyg 70:171-180

22. Devaney MA, Vakharia VN, Lloyd RE, Ehrenfeld E, Grubman MJ (1988) Leader protein of foot-and-mouth disease virus is required for cleavage of the p220 component of the cap-binding protein complex. J Virol 62:4407-4409

23. Dhanda MR, Gopalakrishnan VR, Dhillon HS (1957) Note on the occurrence of atypical strains of foot-and-mouth diseases virus in India. Ind J Vet Sci 27:79-84

24. Diez J, Davila M, Escarmıs C, Mateu MG, Domınguez JJ, Perez E (1990) Unique amino acid substitution in the capsid proteins of foot-and-mouth disease virus from a persistent infection in cell culture. J Virol 64:5519-5528

25. Doel TR (2003) FMD vaccines. Virus Res 91:81-99

26. Domingo E, Escarmis C, Baronowski E, Ruiz-Jarabo CM, Carrillo E, Nunez JI (2003) Evolution of foot-and-mouth disease virus. Virus Res 91:47-63

27. Domingo E, Escarmis C, Martinez MA, Martinez-Salas E, Mateu MG (1992) Foot-and-mouth disease virus populations are quasispecies. Curr Topics Microbiol Immunol 176:33-47

28. FAO (2011) Economic impacts of foot-and-mouth disease outbreaks in the Republic of Korea. (http://www.fao.org/ag/againfo/ home/en/news/archive/2011/economic-impact/FMD.html)

29. Ferguson NM, Donnelly CA, Roy M (2001) Transmission intensity and impact of control policies on the foot and mouth epidemic in Great Britain Anderson. Nature 413:542-548

30. Gebauer F, de la Torre JC, Gomes I, Mateu MG, Barahona H, Tiraboschi B (1988) Rapid selection of genetic and antigenic variants of foot-and-mouth disease virus during persistence in cattle. J Virol 62:2041-2049

31. Goris N, Maradei E, D'Aloia R, Fondevila N, Mattion N, Perez A (2008) Foot-and-mouth disease vaccine potency testing in cattle using homologous and heterologous challenge strains: Precision of the "Protection against podal generalisation test". Vaccine 26:3432-3437

32. Grazioli S, Fallacara F, Brocchi E (2004) Mapping of neutralising sites on FMD virus type Asia 1 and relationships with sites. Rpt. Sess. Res. Gp. Stand. Tech. Comm. Eur. Comm. Control of FMD (FAO), Crete (Greece), Appendix 44, pp 277-287

33. Jackson T, King AM, Stuart DI, Fry E (2003) Structure and receptor binding. Virus Res 91:33-46

34. Kitching R (2005) Global epidemiology and prospects for control of foot-and-mouth disease. Curr Top Microbiol Immunol 288: 133-148

35. Kitson JD, McCahon D, Belsham GJ (1990) Sequence analysis of monoclonal antibody resistant mutants of type $\mathrm{O}$ foot-and-mouth disease virus: evidence for the involvement of the three surface exposed capsid proteins in four antigenic sites. Virology 179:26-34

36. Lombard M, Pastoret PP, Moulin AM (2007) A brief history of vaccines and vaccination. Sci Tech Rev OIE 26:29-48

37. Mahapatra M, Seki C, Upadhyaya S, Barnett PV, Torre JL, Paton DJ (2011) Characterisation and epitope mapping of neutralising monoclonal antibodies to A24 Cruzeiro strain of FMDV. Vet Microbiol 149:242-247

38. Mateu MG, Martinez MA, Capucci L, Andrew D, Giratt E, Sorbino F (1990) A single amino acid substitution affects multiple overlapping epitopes in the major antigenic site of foot-andmouth disease virus serotype C. J Gen Virol 71:629-637

39. Mathew L, Menon DG (2008) Economic impact of FMD in Chazhoor Panchayath. Vet World 1(1):5-6

40. McCullough KC, Crowther JR, Butcher RN (1985) A liquidphase ELISA and its use in the identification of epitopes on footand-mouth disease virus antigens. J Virol Methods 11:329-338

41. Mishra N, Rai DV, Pattnaik B (1995) Strain differentiation of footand-mouth disease virus type Asia 1. Ind J Anim Sci 65:368-374

42. Mohapatra JK, Subramaniam S, Pandey LK, Pawar SS, De A, Das B, Sanyal A, Pattnaik B (2011) Phylogenetic structure of serotype A foot-and-mouth disease virus: global diversity and the Indian perspective. J Gen Virol 92:873-879

43. Mohapatra JK, Pandey LK, Sanyal A, Pattnaik B (2011) Recombinant non-structural polyprotein $3 \mathrm{AB}$-based serodiagnostic strategy for FMD surveillance in bovines irrespective of vaccination. J Virol Methods 177:184-192

44. Newton SE, Carroll AR, Campbell RO, Clarke BE, Rowlands DJ (1985) The sequence of foot-and-mouth disease virus RNA to the $5^{\prime}$ side of the poly $(\mathrm{C})$ tract. Gene 40:331-336

45. Nunez JI, Baranowski E, Molina N, Ruiz-Jarabo CM, Sanchez C, Domingo E, Sobrino F (2001) A single amino acid substitution in 
nonstructural protein $3 \mathrm{~A}$ can mediate adaptation of foot-andmouth disease virus to the guinea pig. J Virol 75:3977-3983

46. Ouldridge EJ, Barnett ITR, Hingley J, Rweyemamu MM (1984) An indirect sandwich enzyme-linked immunosorbent assay for the detection of foot-and-mouth disease virus immunizing antigen in tissue culture harvest. J Biol Stand 12:339-351

47. Parida S (2009) Vaccination against foot-and-mouth disease virus: strategies and effectiveness. Expert Rev Vaccin 8(3): 347-365

48. Pattnaik B, Rai DV, Venkataramanan R (1990) Characterization of type $\mathrm{O}$ foot-and-mouth disease virus isolates recovered from outbreaks in India. Ind J Anim Sci 60:1265-1270

49. Perez AM, Ward MP, Carpenter TE (2004) Control of a foot-andmouth disease epidemic in Argentina. Prev Vet Med 14:217-226

50. Piccone ME, Kaplan G, Giavedoni L, Domingo E, Palma EL (1988) VP1 of serotype C foot-and-mouth disease viruses: longterm conservation of sequences. J Virol 62:1469-1473

51. Radostits OM, Arundel JH, Gay C (2000) Veterinary medicine, a textbook of the diseases of cattle, sheep, pigs, goats and horses, 9th edn. W B Saunders Co., London

52. Rodriguez-Torres JG (2000) International approach to eradication and surveillance for foot-and-mouth disease in the Americas. Ann NY Acad Sci 916:194-198

53. Rueckert RR, Wimmer E (1984) Systematic nomenclature of picornavirus proteins. J Virol 50:957-959

54. Rweyemamu MM, Booth JC, Head M, Pay TWF (1978) Microneutralization tests for serological typing and subtyping of FMD virus strains. J Hyg (London) 81:107-123

55. Rweyemamu M, Roeder P, MacKay D, Sumption K, Brownlie J, Leforban Y (2008) Planning for the progressive control of footand-mouth disease worldwide. Transbound Emerg Dis 55:73-87

56. Rweyemamu MM (1984) Antigenic variation in foot-and-mouth disease: studies based on the virus neutralization reaction. J Biol Stand 12:323-337

57. Ryan MD, King AM, Thomas GP (1991) Cleavage of foot and mouth disease virus polyprotein is mediated by residues located within a 19 amino acid sequence. J Gen Virol 72:2727-2732

58. Sangar DV, Rowlands DJ, Harris TJ, Brown F (1977) Protein covalently linked to foot and mouth disease virus RNA. Nature 268:648-650

59. Sanyal A, Subramaniam S, Mohapatra JK, Tamilselvan RP, Singh NK, Hemadri D, Pattnaik B (2010) Phylogenetic analysis of Indian serotype Asia1 foot-and-mouth-disease virus isolates revealed emergence and reemergence of different genetic lineages. Vet Microbiol 144:198-202

60. Saraiva V (2003) Vaccines and foot-and-mouth disease eradication in South America. Develop Biol (Basel) 114:67-77

61. Saxena R (1994) Economic value of some non-milk losses caused by foot and mouth disease in India. Working Paper 62, Institute of Rural Management, Anand. https://www.irma.ac.in/index.php. Accessed on June, 2011

62. Saxena R (1994) Economic value of milk loss caused by foot and mouth disease in India. Working Paper 60, Institute of Rural
Management, Anand. https://www.irma.ac.in/index.php. Accessed on June, 2011

63. Sorensen KJ, Madsen KG, Madsen ES, Salt JS, Nqindi J, MacKay DKJ (1998) Differentiation of infection from vaccination in foot and mouth disease by the detection of antibodies to the nonstructural proteins $3 \mathrm{D}, 3 \mathrm{AB}$ and $3 \mathrm{ABC}$ in ELISA using antigens expressed in baculovirus. Arch Virol 143:1461-1476

64. Sutmoller P, Barteling SS, Olascoaga RC, Sumption KJ (2003) Control and eradication of foot-and-mouth disease. Virus Res 91:101-144

65. Tam S, Clavijo A, Engelhard EK, Thurmond MC (2009) Fluorescence-based multiplex real-time RT-PCR arrays for the detection and serotype determination of foot-and-mouth disease virus. J Virol Methods 161:183-191

66. Thomas AAM, Woorthmeijer RJ, Puijk W, Barteling SJ (1988) Antigenic sites on foot-and-mouth disease virus type $\mathrm{A}_{10}$. J Virol 62:2782-2789

67. Thompson D, Muriel P, Russell D, Osborne P, Bromley A, Rowland M, Creigh-Tyte S, Brown C (2002) Economic costs of the foot and mouth disease outbreak in the United Kingdom in 2001. Sci Tech Rev OIE 21:675-687

68. Thomson GR (1994) Foot-and-mouth disease. In: Coetzer JAW, Thomson GR, Tustin RC (eds) Infectious diseases of livestock with special reference to southern Africa. Oxford University Press, Cape Town, pp 825-952

69. Tosh C, Sanyal A, Hemadri D, Venkataramanan R (2002) Phylogenetic analysis of serotype A foot-and-mouth disease virus isolated in India between 1977 and 2000. Arch Virol 147:493-513

70. Vakharia VN, Devaney MA, Moore DM, Dunn JJ, Grubman MJ (1987) Proteolytic processing of foot-and-mouth disease virus polyproteins expressed in a cell-free system from clone-derived transcripts. J Virol 61:3199-3207

71. Valarcher JF, Knowles NJ, Zakharov V, Scherbakov A, Zhang Z, Shang YJ (2009) Multiple origins of foot-and-mouth disease virus serotype Asia 1 outbreaks, 2003-2007. Emerg Infect Dis 15:1046-1051

72. Vangrysperre W, De Clercq K (1996) Rapid and sensitive polymerase chain reaction based detection and typing of foot-andmouth disease virus in clinical samples and cell culture isolates, combined with a simultaneous differentiation with other and/or symptomatically related viruses. Arch Virol 141:331-344

73. Venkataramanan, R., Hemadri, D., Bandyopadhyay, S.K., Taneja, V.K. (2006) Foot-and mouth disease in India: present status. Paper presented at a workshop on Global Roadmap for improving the tools to control foot-and-mouth disease in endemic settings. 29 Nov-1 Dec 2006, Agra

74. Xie QC, McCahon D, Crowther JR, Belsham GJ, McCullough KC (1987) Neutralization of foot-and-mouth disease virus can be mediated through any of at least three separate antigenic sites. J Gen Virol 68:1637-1647 